\title{
Androcentrism of English proverbs and Anti-Proverbs with Gender Components
}

\author{
Maria Kirsanova \\ National Research University Higher School of Economics
}

\begin{abstract}
Correspondence concerning this article should be addressed to Kirsanova Maria, National Research University Higher School of Economics, Old Basmannaya Str., 21/4, building 4, office. B-209, Moscow, Russian Federation, 105066. E-mail: mkirsanova@hse.ru
\end{abstract}

\begin{abstract}
Since the $20^{\text {th }}$ century with the birth of feminism, gender studies have undergone analysis in many areas of knowledge. Special attention has been paid to the theory of androcentricity in the English language and the deficiency of female images in speech. In this article, the images of men and women presented by English proverbs and anti-proverbs are analyzed. The objective of this research is to find out if proverbs are androcentric and present male mindsets and world views. The other aim is to check whether anti-proverbs reflect the changing role of women in society. To fulfill these purposes, proverbs with gender components (man/woman, wife/husband, he/she etc.) were selected and underwent a semantic analysis. In order to reveal the evolution of the images of men and women we compared the images of men and women illustrated in proverbs with those shown in anti-proverbs with the same gender components. As a result, we came to the conclusion that both proverbs and anti-proverbs are androcentric; however, in anti-proverbs female opinions are more representative when compared to proverbs. To sum up, it is obvious that the role of women is changing and the changes are reflected in the language.
\end{abstract}

Keywords: gender, proverbs, anti-proverbs, male, female, androcentrism

With the beginning of the twentieth century, the issue of androcentricity and gender asymmetry in the English language has become one of the most debatable in society.

The term androcentrism was introduced by Charlotte Perkins Gilman in the research "The ManMade World or, Our Androcentric Culture", published in 1911. According to Perkins Gilman, androcentrism can be understood as cultural perspectives where the male is generically taken to be the norm of humanness. It means that masculinity is normative and all things that do not refer to masculinity are defined as other. Thus, masculinity is normative and all things outside masculinity are defined as other.

In 2015-2016 the problems of self-identification provoked vehement debates and put the focus back on the gender representation in a language. According to many researchers (Lakoff 1975, Spender 1980) the English language is androcentric and expresses malecentered culture and an unequal position of men and women in society.

The problem of representation of gender in a language has been studied in a wide range of disciplines such as cultural studies, anthropology, education, art history, philosophy, linguistics, psychology, and psychoanalysis (Wilhelm von Humboldt (1836), Mills
(1995), Roman, Juhanz, and Miller (1994).

The study of connection between language and sex dates back to the ancient times when the grammatical category "gender" started to be considered. For a long time, researchers connected biological sex with the grammatical category gender. In other words, it was believed that the grammatical category of gender arose because of the existence of different sexes. This theory was supported by scientists such as W. Humboldt and others.

At the beginning of 20th century the problem of sex reflection in a language attracted the attention of $\mathrm{F}$. Mautner. In 1901-1903, F. Mautner's work on criticisms of the language was published. He emphasizes the metaphorical nature of the language. It means that native speakers transfer their non-linguistic experience into linguistic expression, and, thus, it determines the subjectivity of our picture of the world. Having studied the grammatical gender of nouns in German, F. Mautner concludes that the grammatical division into gender is a metaphor as it associates an object with masculine of feminine characteristics.

O. Jespersen (1922) in his book "Language: Its Nature and Development, and Origin" stated the idea that women's language is deficient and subordinate.

In 1949, a book by Simone de Beauvoir entitled 
"The Second Sex" appeared in France. According to the author of this book, stereotypes of men and women are fixed in history. The author connects a man with the sphere of "constructing the meaning of life" - culture and society, and women take part in such spheres of life as reproduction and nature.

In the late 60 's and 70 's of the $20^{\text {th }}$ century, scientists began to pay attention to gender studies thanks to the "New Women's Movement" (as cited in Potapov, 2002). This movement gave birth to a new branch of linguistics - feminist linguistics, or feminist criticism of the language.

Among the main works on feminist criticism of the language the study of R.Lakoff "Language and Woman's Place", which was published in 1975, plays the main role. This work proves androcentricity (an orientation toward men) and the defective image of a woman in the world picture reproduced in the language. This theory is called the theory of "deficiency" of female speech. R. Lakoff examines the notion of "female language" and "male language" (Lakoff, 1975). According to this work, a woman's speech is characterized by the following traits: she is insecure, her speech is less aggressive than a man's speech, she is more humane in relation to the interlocutor. Men try to take a dominant position, they are more aggressive, unwilling to compromise.

The theory of "deficiency" of female speech, introduced by R. Lakoff, was developed in the "theory of two cultures", implemented by her student, the famous American scientist D. Tannen. In the work "You Just Don't Understand: Women and Men in Conversation" (1990), D. Tannen analyzes male and female speech tactics and concludes that the dialogue between men and women is a dialogue between two opposite worlds and cultures. It means that the same conversation can be understood by men and women differently and lead to quarrels and misunderstandings.

In feminist linguistics there are two branches: the first and the main branch is devoted to the identification of the language asymmetry, reflecting the male picture of the world, i.e. language sexism. In this case, patriarchal stereotypes that give women a subordinate and dependent role are under analysis.

The basis for the study of feminist linguistics has become the lexicon of European languages, since it most clearly traces the subordinate position of women. For example, in a number of European languages, the same lexical unit is used for the notions of "man" and "person". In English, the word "man" has both meanings (The Oxford English dictionary).

The second issue, which feminist linguistics concentrate on, is problems and characteristics of gender communication in mixed and same-sex groups. Material for analysis was drawn from a variety of sources, for example, conversations between doctors and patients, talk shows, and socializing in the family.
The studies of feminist linguistics were based on the assumption that the strategies of speech behavior of men and women differ from each other. Moreover, they differ depending on whether the conversation takes place in a same-sex or in a mixed-sex environment (Hancock \& Rubin, 2014).

A special place in language and culture studies is occupied by proverbs, since cultural and national traditions are recorded via proverbs in order to be passed on through generations.

In this article, proverbs are considered as aphoristic sayings with an instructive meaning and are rhythmically organized (Koonin, 1996). Proverbs are a list of rules and norms of behavior, in which the national cultural code that regulates people's relations and gives a base for self-identification are displayed. Using this source, a native speaker generalizes and assimilates experience, values, moral norms, and prescriptions for the society. Therefore, by analyzing the proverbs of the English language with gender components, it is possible to draw a conclusion about the stereotypes of men and women fixed in this culture.

For example:

\section{A woman's tongue wags like a lamb's tail} (Kershen, 1998, p.180).

This proverb has a negative connotation and illustrates the assumption that women are too talkative and they never control their speech. Because of this, a man should not treat a woman seriously.

Being subject to various changes by extra- and intralinguistic factors, proverbs adapt to new problems and circumstances. Dealing with this or that situation, a person correlates it with a similar situation, illustrated in a proverb, and follows the example. However, proverbs are continuously used and undergo changes adapting to new realities. It should be mentioned that, despite the seeming randomness of such substitutions, they meet a kind of "social order", reflecting the changes of reality in a language. Thus, the formation of anti-proverbs is taking place which means adjustment of "old" proverbs to new life situations.

The term "anti-proverb" is quite new in linguistics. An analysis showed that, by 2005 , it was quite actively used in paremiological studies (Mieder (1989); Gossler (2005); Foldes, A., Litovkina A.T., Mieder W. (2006) Batulina (2009); Smirnova (2009); Antonova (2010), etc.). However, it was not fixed in any terminological dictionary of the corresponding disciplines (Walter \& Mokienko, 2005).

This term is a calque from the German Antisprichwort, was first introduced by W. Meader, one of the well-known modern scientists who, since 1982, has published (one or in co-authorship) several large dictionaries of anti-proverbs in German and English (Mieder 1989; Mieder, 2002). W. Meider characterizes 
anti-proverbs as twisted (warped, distorted) wisdom (German verdrehte Weisheiten, English twisted wisdom) (Walter, Mokienko 2005,). In this paper antiproverbs are defined as transformed paremia, which have undergone structural and semantic changes.

For example:

Man proposes - but not always marriage / Man proposes, God disposes (Mieder, 2002, p.137).

This anti-proverb is formed by cutting one part and adding a new one, completely different from the original one. In this case, it is necessary to note the change in the semantic of the lexical unit "man". So, if in the traditional paremia the lexeme "man" has the meaning "person", since in this proverb does not contain a direct indication of gender, then in the antiproverb lexical unit "man" clearly indicates a male human. Thus, in this anti-proverb has an absolutely different meaning. In this case this paremia plays a role of a warning that men do not always keep their word.

The difference between proverbs and anti-proverbs is demonstrated by the fact that anti-proverbs are variations of traditional proverbs and they are ironic and humorous. They can elicit humorous effect only if the violation of expectation is applied: the original proverb is well known, thus the reader is able to perceive and understand the discrepancy.

In this study, attention is paid to gender-marked anti-proverbs because they reflect the changes that take place in society.

This research contributes to identifying gender asymmetry in the English language as it is devoted to studying gender asymmetry, which is reflected by means of English proverbs and anti-proverbs with gender components.

The first goal of the research is to analyze proverbs in the English language with gender component and prove that the English language is androcentric and this is reflected in proverbs Moreover, it is necessary to understand whose assessment, men's or women's, is reflected in the proverbs.

It is common knowledge that nowadays men and women are becoming more and more equal in their rights and society is endeavoring to treat them equally. Therefore, it seems very interesting to find out if the paremiology of the English language reflects this tendency and if the images of men and women represented by proverbs are different from the images represented by anti-proverbs. Thus, the second aim of the research is to compare the images of men and women presented in proverbs with the images presented in anti-proverbs in the English language with gender components to find out if there have been any changes in the picture of the world.

The relevance of this research is that proverbs with gender components reflects national ideas and traditions about men and women's roles in society, about requirements which representatives of both sexes have to meet, and about differences in character and behavior of men and women. These images, which have been formed over centuries, define modern gender relationships. Moreover, the evolution of these relationships is illustrated by means of antiproverbs, so it allows us to analyze the representation of men's and women's images in modern language. Thus, in this research for the first time proverbs with gender components are separated from proverbs with components "man" meaning "person". In addition, the images reflected in proverbs are compared with images illustrated in anti-proverbs. The hypothesis of the research is that proverbs and anti-proverbs in the English language are androcentric and reflect the male perspective.

\section{Method}

\section{Materials}

To conduct the analysis 353 proverbs and 83 antiproverbs were selected from such dictionaries as Clay Doyle, Mieder W. The Dictionary of Modern Proverbs (2012), Preston. A Dictionary of English Proverbs and Proverbial Phrases (2012), Simpson, J., Speake J., Concise Oxford Dictionary of Proverbs (1994), Mieder W., Steward W., Kingsbery A., and Kelsie B A Dictionary of American Proverbs (1992), Titelman G. Random House of America's Popular Proverbs and Sayings (2000), Stevenson B. The Macmillan Book of Proverbs (1948), Kershen A. American Proverbs about Women (1998), Fergusson R, The Penguin Dictionary of Proverbs (2001), Apperson G. L, Wordsworth Dictionary of Proverbs. (1993), Gratian V. The Sterling Book of proverbs (1998), and Bartlett J.W Early American Proverbs and Proverbial Phrases (1977).

For the purpose of selecting the linguistic material, the following criteria were taken into account: 1) the correlation with the topic 2) cultural value, 3) the presence of a gender component in the semantics.

There are different forms of gender representation in English paremiology. First of all, it is impossible to take into consideration only gender differences, since in English there is no gender as a grammatical category. Consequently, the gender component can be fixed only with the help of gender-marked lexical units. A set of lexical units that are gender-marked can be divided in three groups:

1. anthropometric lexical units. For example, man-woman, boy-girl, gentleman-lady, he-she. While analyzing proverbs with the components "man" and "woman", it should be mentioned 
that the word "man" has two meanings according to the Oxford English Dictionary: 1. A human being (irrespective of sex and age); 2 . The meaning "person" occurs only in general or indefinite application; in modern application man primarily denotes the male sex [http:// public.oed.com]. The American Heritage Dictionary of English Language provides two definitions as well: 1) An adult male human 2) A human regardless of sex (The American Heritage Dictionary of the English language). Thus, it is necessary to analyze proverbs and anti-proverbs with the component "man" meaning "person" and component "man" meaning "male human" separately.

For example,

A man can do no more than he can (Apperson, 1993, p.364).

In this case, a person in general is characterized but not a man.

2. kinship terms. For example, wife-husband, daughter-son, mother-father.

3. anthroponymic lexemes (proper names). For example, Jack-Jill.

4. In a separate group, we can distinguish components that are not gender markers by themselves: fool, flower. For example:

The handsomest flower is not the sweetest

(Stevenson, 1948, p.835).

In this proverb there is no direct indication of the gender of the referent. This example can be applied to both men and women. The proverb warns against hasty conclusions, which can only be made based on appearance.

\section{Methodology}

To conduct this research we applied a semantic analysis in order to distinguish proverbs and antiproverbs containing typical characteristics of men and women that native speakers of the English language possess.

This semantic analysis of proverbs and antiproverbs helps divide the paremeological units into three groups describing various characteristics of humans:

- biological characteristics including age, appearance, and sexuality.

- moral and psychological characteristics containing such traits as intelligence, feeling, emotions as well as such behavioral characteristics as bravery, grumpiness, chattiness, etc.
- social characteristics including stereotypical roles of men and women in their societies and families, spheres of human activity.

Then, the images of men and woman belonging to each group underwent analysis in order to evaluate these images and find out how societies treats men and women.

\section{Procedure}

The research is divided into two parts. Firstly, we studied proverbs with the component man" meaning "a person" in order to differentiate the proverbs describing people in general and the ones describing male humans. Secondly, proverbs with gender components belonging to each group underwent analysis and the images of men and women were compared in order to find out the qualitative characteristics. For example, concerning the first group, which includes biological characteristics, we analyzed how society treats age and appearance of men and women. In order to evaluate the images we focused on the meaning of proverbs and on the traits and characteristics of the people that these proverbs criticize or praise.

For example, When an ass climbs a ladder, we may find wisdom in women (Apperson, 1993, p.28)

This proverb illustrates the belief that women cannot be intelligent: women are compared to a donkey which cannot climb a ladder. As a donkey is not able to climb the ladder, it is impossible for women to become wise. Furthermore, the usage of the modal verb "may" shows that a donkey climbing a ladder is more likely to happen.

The next step was to analyze anti-proverbs. Like traditional paremias, they were divided into three groups according to the characteristics they reveal. Then, we analyzed the images of men and women illustrated by these anti-proverbs and compared them to the images reflected by the proverbs in order to see if the evolution of these images can be discerned. Then, the conclusion about androcentricity of English paremias was made.

\section{Results and discussion}

The analysis of English proverbs and anti-proverbs with gender components has allowed us to make the following conclusions.

First of all, the quantitative analysis shows that the proverbs which describe women are the most numerous (see Table 1). 
Table 1

The Number of Proverbs with Gender Components

\begin{tabular}{lc}
\hline Proverbs & Quantity (\%) \\
\hline Proverbs about a person in general & 13 \\
Proverbs focusing on men & 20 \\
Proverbs focusing on women & 67 \\
\hline
\end{tabular}

The analysis of the proverbs with the component "man" meaning "person" found that very few proverbs describe biological characteristics such as appearance and age. It should be noted that proverbs with the component "man" meaning "person" account only for about $1 \%$ of the selected material. This situation seems reasonable, as approaches to the male and female appearance and evaluations of the attractiveness of men and women are completely different. That is why the proverbial standard of beauty is not fixed in proverbs. The same situation is relevant to the evaluation of age.

The handsomest flower is not the sweetest (Stevenson, 1948, p.835).

This proverb does not contain the component "man", yet the metaphor is used and a person is meant.

Men's years and their faults are always more than they are willing to own (Bohn, 1855, p. 452).

In this proverb the comparison between faults and age is obvious so it proves that the age is negatively evaluated.

In proverbs that describe moral and psychological characteristics of such qualities as intelligence, hard work, honesty, and strong will are praised. The qualities that are criticized by society are envy, laziness, selfishness, cowardice, despondency, and anger

An honest man is the noblest work of God (Mieder, 1992, p.504).

Early to bed and early to rise makes a man healthy, wealthy and wise (Mieder, 2002, p.73).

An angry man opens his mouth and shuts his eyes (Bohn, 1855, p.310).

An envious man waxes lean with the fatness of his neighbor (Apperson, 1993, p.175).

Social characteristics are reflected in proverbs conceptualizing roles of people in family and society.

It should be noted that proverbs belonging to this level have not been identified. It can be explained by the fact that women and men were assigned different social roles, since they held different positions in a society.

The analysis of English proverbs shows that they reflect the male picture of the world and male authority.

Focusing on the paremiological units with gender components it should be stated that in general, the stereotype of a man, expressed in the language, includes those qualities that are highly appreciated in patriarchal-type cultures, for example: physical strength, intellectual superiority, rationality, aggressiveness, sexual activity, independence, and power over others. The stereotyped image of a woman is represented by qualities that are assessed negatively in the patriarchal world, namely: dependence, sexual attractiveness, emotionality, and sensitivity.

Concerning physical and biological characteristics, it should be stated that there are different attitudes towards appearance. For men, appearance is not as important as for women. There is only one proverb describing men's appearance and at the same time, the number of proverbs giving positive characteristics to women's appearance is not large - only $1 \%$.

A man is a man if he has but a nose on his face (Fergusson, 2001, p.235).

A fair face is half a portion (wedding - portion) (Bohn, 1855, p.285).

However, even physical attractiveness can be assessed negatively (5\%).

Three things breed jealousy: a mighty state, a rich treasury and a fair wife.

Like appearance, society also treats the age of men and women differently: an old man is wise. It is proved by $4 \%$ of our material. There are several proverbs that criticize man illustrating the lack of power and their uselessness for a society, yet they are not numerous (2\%). In contrast, the stereotypical image of an old woman is negative as not a single proverb with positive characteristics of old women was identified. Moreover, negative traits of character increase while she is getting older.

Men grow weaker and wiser (Stevenson, 1948, p.2139).

A woman is an angel at ten, a saint at fifteen, a devil at forty, and a witch at fourscore (Stevenson, 1948, p.2569)

Speaking about moral characteristics, proverbs with gender components meaning "women" are found in larger numbers than proverbs about men, $13 \%$ and $26 \%$ respectively. Moreover, it should be noted that in comparison to women, men are less evil and dangerous.

Man, woman, and devil are the three degrees

of comparison (Bohn, 1855, p.448).

$A$ bad woman is worse than a bad man (Kershen, 1998, p.75).

In English proverbs such traits of women's character as unpredictability and insidiousness are emphasized. Moreover, the image of a woman is closely connected with the image of the devil and hell.

Women are the snares of Satan (Mieder, 1992, p.445).

A wicked woman and an evil are three halfpence worse than the devil (Bohn, 1855, p.45). 
According to proverbs, women are not intelligent. Women have long hair and short brains (Mieder, 1992, p.441).

However, women are respected for their intuition but not logical thinking.

A man thinks he knows, but a woman knows better (Kershen, 1998, p.152).

Women's instinct is often truer than men's reasoning (Gratian, 1998, p.184).

It should be noted that the number of proverbs about female stupidity is not much greater than the number of men's.

Men talk wisely but live foolishly (Stevenson, 1948, p.508).

If men talked about what they understood, the silence would be unbearable (Mieder, 1992, p.679).

However, it must be taken into account that often stupidity is regarded as a universal vice, and the intelligence is regarded as mostly a male characteristic.

In general, the superiority of the male mind is proclaimed in English proverbs not in the number of corresponding units, but through the emphasis on female stupidity.

As mentioned above, a positive image of men prevails in the picture of the world presented by proverbs. Such characteristics of men as courage, fidelity, strength of character, and persistence are praised by the society $(6 \%)$.

A man without purpose is like a ship without a rudder (Mieder, 1992, p.674).

Man is a lion in his own cause (Stevenson, 1948, p.304).

A man of words and not of deeds is like a garden full of weeds (Stevenson, 1948, p.2615).

It is impossible to claim that men are absolutely free of vices, yet most of these vices characterize humanity as a whole:

An angry man opens his mouth and shuts his eyes.

A man wrapped in himself makes a very small bundle (Mieder, 1992, p.674).

A man can smile and smile and still be a villain (Mieder, 1992, p.872).

An envious man waxes lean with the fatness of his neighbor (Apperson, 1993, p.175).

Among purely male vices a special place is occupied by drunkenness and lechery.

A man takes a drink and then the drink takes the man (Mieder, 1992, p.238).

Gaming, women and wine make men pine (Apperson, 1993, p.226).

At the same time, there are a lot of proverbs (24\%) that give a negative assessment to women. A woman is characterized by such features as a weak and illogical mind, immaturity, extreme emotionality, unpredictability, danger, insidiousness, and chattiness. Women are as wavering as the wind (Gratian, 1998, p.183).

Swine, women, and bees cannot be turned (Kershen, 1998, p.71).

A woman's tongue is the last thing about her that dies (Stevenson, 1948, p.2580).

A woman's thoughts are afterthoughts (Gratian, 1998, p.183).

Women are saints in church, angels in the streets, and devils at home (Mieder, 1992, p.915).

In proverbs reflecting the images of women such characteristics as beauty and youth are assessed politely but there are some paremiological units that shows that virtue and goodness are more important.

A fair woman without virtue is like palled wine (Fergusson, 2001, p.181).

A wife is not to be chosen by eye only

(Kershen, 1998, p.63).

An analysis of proverbs that reflect social characteristics show that there was a clear division of labor in society: men support a family, and women engage in the households.

When Adam delved and Eve span who was then a gentleman? (Apperson, 1993, p.12).

It is interesting to mention that professional achievements are not always evaluated positively from the female point of view

The worse the husband, the better the soldier (Stevenson, 1948, p.2157).

The better workman, the worse husband (Apperson, 1993, p.53).

Concerning women, it should be mentioned that the analysis of the proverbs showed that the only sphere of activity available to women and reflected in paremia is housekeeping. A woman is a mother, a wife, a mistress in the kitchen, and a sexually attractive object. According to traditional ideas, the woman is the keeper of the hearth who should provide comfort in the house and this is one of the most important roles of a woman. This idea is supported by proverbs:

A woman's place is in the home (Mieder, 1992, p.856).

Men build houses, women build homes

(Mieder, 1992, p.525).

Due to the fact that the main aim of women was to get married, there are a lot of proverbs that show the qualities an ideal wife should possess. Such qualities as kindness, good faith, economic management, fidelity, etc. are positively evaluated. A good wife is a pride for her husband. The atmosphere in the house and the life of husband depend on a wife. The importance of a wife is proved by $8 \%$ of proverbs.

A good wife and health is a man's best wealth (Kershen, 1998, p. 21).

A cheerful wife is the joy of life (Gratian, 1998, p. 
110).

Two things do prolong life: a quiet heart and a loving wife (Apperson, 1993, p. 601).

Such qualities of wives as grumpiness, inability to conduct business, extravagance, etc. are severely criticized. This criticism is illustrated by $18 \%$ of the proverbs.

A sloppy, wasteful woman will waste and carry out more in her apron than an ambitious man can haul in a wagon (Mieder, 1992, p. 908). It's better to dwell in the corner of a housetop than with a brawling woman in a wide house (Cordy 2005, p. 130).

Three things drive a man out of his house smoke, rain and a scolding wife.

It is interesting to notice that there are no proverbs which give any recommendations to men. This fact proves that the English language is androcentric.

Another very important role of a woman is motherhood, which is respected by society ( $2 \%$ of the analyzed proverbs). Women's roles as mothers are traditional roles and associated with traditional gender attitudes. It is the most important role of women in patriarchal societies (Zhou, 2017). In English, proverbs featuring the kindness and affection of mothers are illustrated.
A mother's heart never grows old (Preston, 2012, p.102).
The mother's breath is always sweet (Preston, 2012, p.102).
A man's mother is his own God (Preston, 2012, p.102).

To sum up, it is obvious that women and women's activities are opposed to men and men's activities. The evaluation of activities reflects the male perspective, reflecting androcentrism of the linguistic picture of the world. The main results of this research can be illustrated by the following graphs.

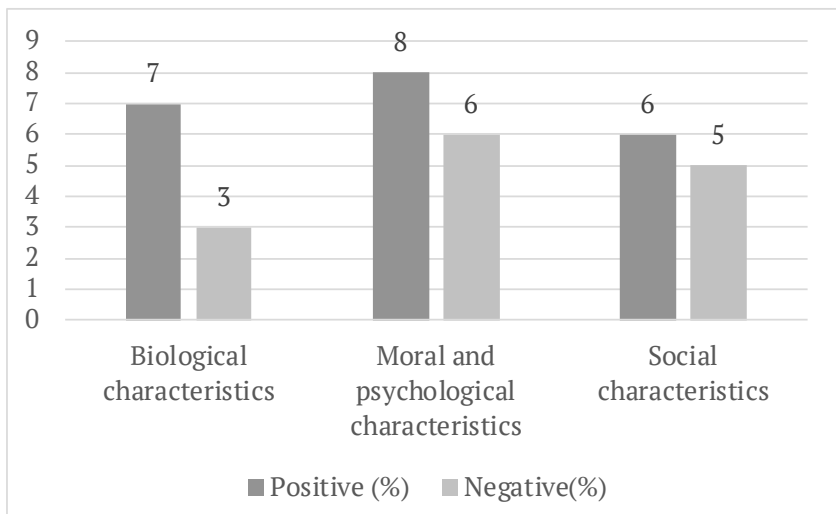

Figure 1.

Characteristics of Men Reflected in Proverbs with Gender Components.

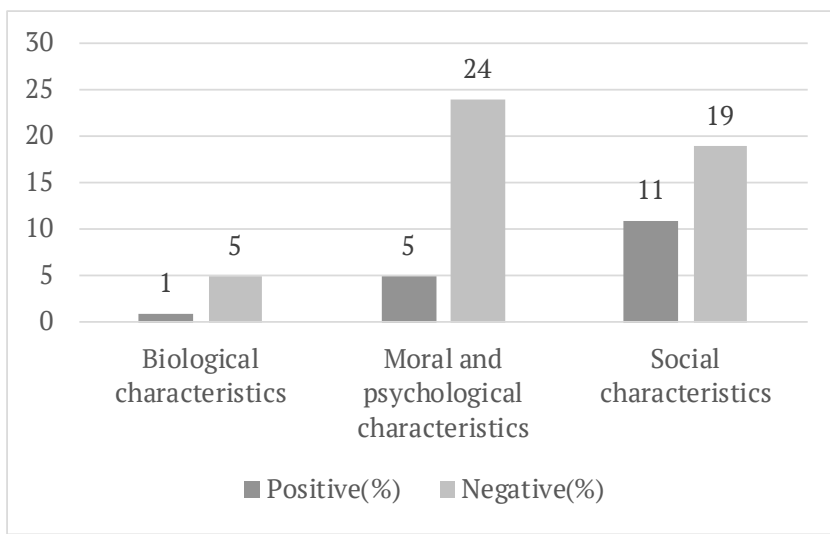

Figure 2.

Characteristics of Women Reflected in Proverbs with Gender Components.

The study shows that English proverbs emphasize negative characteristics of women, which are more numerous.

In English proverbs, women, in contrast to men, are characterized mainly negatively. The value asymmetry of gender concepts can be traced in most frames and reflects the general tendency of patriarchal culture to rate a man higher than a woman. According to the representativity of negative assessments of women, the psychological layer is leading (see Figure 2). The overwhelming majority of the proverbs that form this layer attribute negative moral and moral qualities and low intellect to women. Such qualities as attractiveness, youth, and motherhood are respected.

Men are attributed both positive and negative moral and personal qualities: courage, honesty, integrity, cunning, a quick temper, etc., yet positive characteristics prevail (See Figure 1). The assessment reflects either a male or a universal perspective. However, the assessment from the female point of view is rare.

Thus, proverbs in the English language reflect a predominantly androcentric worldview, i.e. male perspective, negligent, consumer attitude towards a woman.

Concerning anti-proverbs it should be stated that this analysis shows that anti-proverbs about women still prevail (See Table 2). Moreover, we did not find proverbs with component "men" meaning "person" as the word "person" is used.

Table 2

The Number of Anti-Proverbs with Gender Components

\begin{tabular}{lc}
\hline \multicolumn{1}{c}{ Proverbs } & Quantity (\%) \\
\hline Anti-proverbs focusing on men & 38 \\
Anti-proverbs focusing on women & 62 \\
\hline
\end{tabular}

The analysis of anti-proverbs, including biological and physical characteristics, which account for $24 \%$ of 
the material, showed that significant changes in this area have not occurred. There are no anti-proverbs focusing on the appearance of men. As for women, in anti-proverbs the close attention to women's appearance is reflected. Thus, these paremias also reflect an androcentric worldview.

Hell has no fury as a woman unadorned / Hell has no fury like a woman scorned (Mieder, 2002, p. 97).

Like in proverbs, in anti-proverbs the ages of men and women are treated differently.

A man is always as young as he reels.

A man is as old as his arteries.

A man is as old as she feels.

A man is as young as he feels after playing with children.

A man is as old as he looks before shaving, and a woman is as old as she looks after washing her face.

A woman is as old as she looks before breakfast.

A woman is as old as she looks until she puts her face on (Mieder, 2002, p.15).

Men's ages are assessed according to their physical activity while for women looking young is still the most important problem. All these anti-proverbs prove that appearance comes first when we speak about woman. Age is assessed according to how she looks.

It is emphasized that appearance can be deceptive, and beauty is false.

Appearances are deceiving: many a girl who puts up a swell front in public is flat-chested at home / Appearances are deceptive. (Mieder, 2002, p. 43).

For men, appearance, as before, does not play a primary role; status and financial position do, and appearance is determined by physical endurance and self-perception. There were no anti-proverbs focusing on male vices, which suggests that there have been no significant changes at this level.

The anti-proverbs which illustrate the moral and psychological characteristics of men, unlike traditional proverbs, show mostly women's points of view due to the fact that most of them are ironic. However, they do not appear in large numbers and account for $11 \%$ of the analyzed anti-proverbs.

A good man is hard to find / Good men are scarce (Clay Doyle, 2012, p.17).

Men are only good for one thing - and sometimes they aren't even good for that/Men are only good for one thing (Clay Doyle, 2012, p.101).

The anti-proverbs representing the moral and psychological characteristics of women are numerous (32\%) and mostly ironic. Moreover, an emphasis is placed on negative qualities, such as capriciousness, laziness, vindictiveness, etc. Therefore, anti-proverbs also reflect the androcentric picture of the world.

Beware of women bearing gifts: remember Eve /
Beware of Greeks bearing gifts (Mieder, 2002, p. 53). A woman's word is never done / A woman's work is never done. (Mieder, 2002, p. 28).

A woman on time is one in nine / A stitch in time saves nine. (Mieder, 2002, p.24)/

In the English anti-proverbs characterizing men, the female ironic view of men is reflected. The anti-proverbs which represent social characteristics illustrate that the most obvious changes have happened in the social sphere of life (29\%).

First of all, men and women are becoming equal in their rights and, nowadays, keeping a home is not only women's responsibility.

A man's home is his castle; let him clean it / A man's home is his castle.

A married man's home is his castle, with him being the vassal (Mieder, 2002, p.18).

No man can serve two masters, unless he has a wife and a grown-up daughter / No man can serve two masters (Mieder, 2002, p.154).

A married man and his money are soon parted / A fool and his money are soon parted (Mieder, 2002 p.10).

Secondly, this group is characterized by anti-proverbs, indicating the expansion of women's activities.

A woman's place is in the car / A woman's place is in the home (Mieder, 2002 p.26).

However, the opinion about women's ability to drive a car is very ironic.

A woman driver is known by fenders she keeps / A man is known by the company he keeps (Mieder, 2002, p. 16).

Hell hath no fury like a woman driver / Hell has no fury like a woman scorned (Mieder, 2002, p.97).

According to these anti-proverbs women have the opportunity to drive cars but it is obvious that they cannot do it properly. It should be mentioned that we were not able to find any anti-proverbs criticizing men's ability to drive a car.

Now a woman can enter any profession, and she is able to able to climb to the top of the career ladder.

A Woman's Place Is in the House... and in the

Senate / A woman's place is at home (Mieder, 2002 p.26).

The sphere of family life has undergone significant changes too, so these changes are reflected in antiproverbs. On the one hand, there are anti-proverbs declaring the independence of women and the lack of the usefulness of marriage. On the other hand, a number of anti-proverbs emphasize the importance of a happy family life.

A woman without a man is like a fish without a bicycle / $A$ woman without a man is like a handle without a pan (Mieder, 2002, p. 25).

A man's castle is his home, and his wife has the 
key to all the rooms / A man's home is his castle (Mieder, 2002, p.18).

It should be noted, that having conducted the research, we did not find any anti-proverbs about a woman as a mother. This fact can be explained by the idea that antiproverbs are a kind of humorous saying, and the image of a woman as a mother cannot be ridiculed. Since antiproverbs are humorous in nature, they serve as a way of ridiculing women's shortcomings, such as gossip, non-punctuality, etc. Estimates reflect mainly the male perspective.

The results of the analysis are illustrated in Figure 3 and Figure 4.

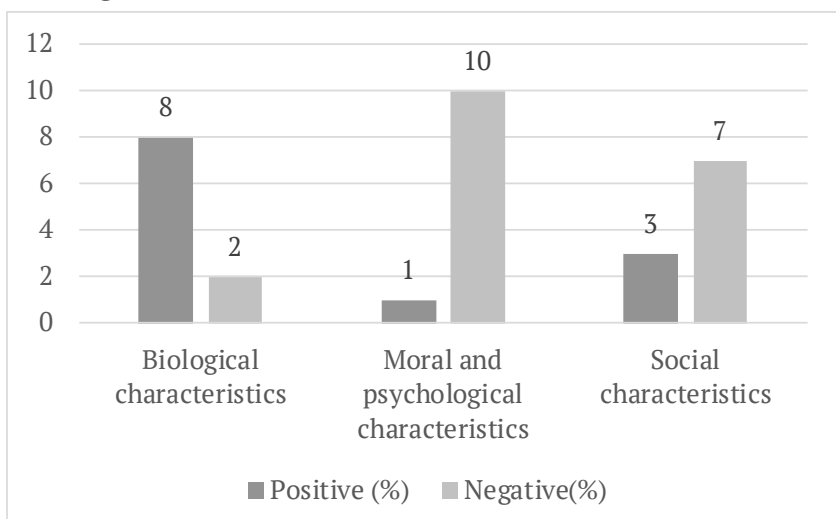

Figure 3.

Characteristics of Men Reflected in Anti-proverbs.

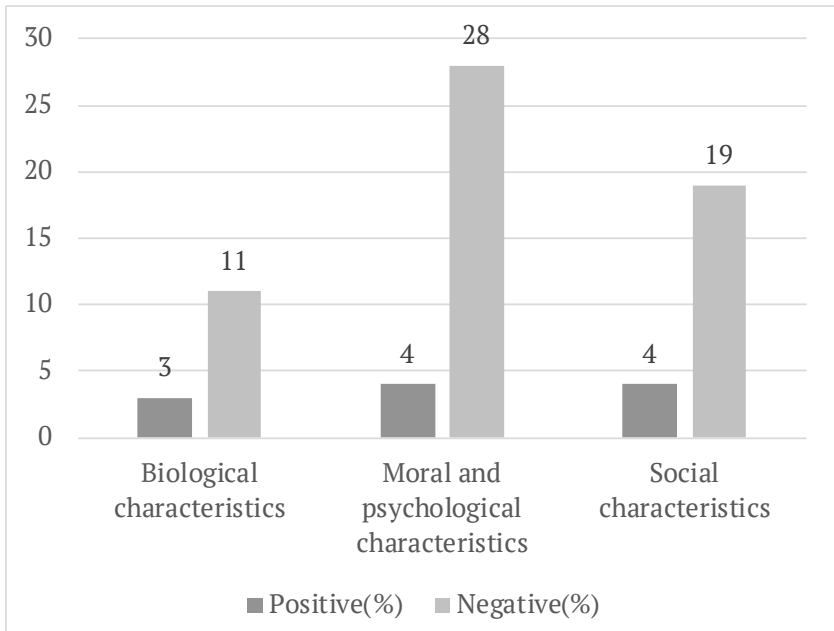

Figure 4.

Characteristics of Women Reflected in Anti-proverbs.

To sum up, it should be mentioned that the analysis of anti-proverbs with gender components proves that the English language is still androcentric and in antiproverbs, women characteristics, especially negative ones, prevail and are emphasized. However, there is a tendency to criticize men as well. Figure 3 illustrates that in the groups of biological characteristics and moral characteristic the emphasis is on the criticism of men.

\section{Conclusion}

The comparative analysis of proverbs and antiproverbs with gender components leads us to the conclusion that there are asymmetrical representations of "male" and "female" in proverbs. Women and women's activities are opposed to men and men's activities. The image of women is characterized mostly by negative traits while the negative traits of men are often attributed to people in general. Assessment characteristics are asymmetric and, as a rule, reflect the male perspective. This fact proves that proverbs and anti-proverbs in the English language are androcentric.

It appears promising to continue studying antiproverbs in order to distinguish and analyze the changes that are happening in the social roles of men and women. It seems obvious to compare images of men and woman represented by proverbs in the English and Russian languages, since the methods of studying parmeology can be used with other languages as well.

\section{References}

Antonova, O.N. (2012). Funkcionalnye svojstva paremij transformov $\mathrm{v}$ angloyazychnom publicisticheskom diskurse [Functional peculiarities of transformed proverbs in the English-language in publicistic discourse] (Unpublished doctoral dissertation thesis). Moscow State Institute of International Relations, Moscow, Russia.

Apperson, G. L. (1993). Wordsworth Dictionary of Proverbs. Ware, Hertfordshire, GB: Wordsworth Editions Ltd.

Bartlett, J. W. (1977) Early American Proverbs and Proverbial phrases. Harvard, USA: Harvard University Press.

Batulina, A. (2009). Techniques of Creating Humorous Effect in Anti-proverbs. Bulletin of Voronezh State Agricultural Academy, 2(12), 94-103.

Beauvoir, S. (1949). Le Deuxième Sexe [The Second Sex] (vol. 2). Paris, France: Gallimard.

Bohn, H. G., \& Ray, J. (1855) A Hand-book of Proverbs: Comprising Ray's Collection of English Proverbs. London, GB: H.G. Bohn.

Clay Doyle, Ch., Mieder, W. (2012). The Dictionary of Modern Proverbs. Yale: Yale press.

Cordy, V. H. (2005) The Multicultural Dictionary of Proverbs. London, GB: McFarland \& Company Inc. Publishers. Fergusson, R., \& Law J. (2001). The Penguin dictionary of proverbs. London, GB: Penguin Books.

Foldes, A., Litovkina A.T., \& Mieder W. (2006). Old Proverbs Never Die, They Just Diversify: A Collection of 
Anti-proverbs. Burlington, Canada: The University of Vermont.

Gossler, E. (2005). Besser arm dran als Bein ab. AntiSprichwörter und ihresgleichen [Anti-proverbs and others]. Wien, Austria: Edition Praesens.

Gratian, V. (1998). The sterling book of proverbs. New Delhi, India: Sterling Publishers Pvt. Ltd.

Hancock, A.B., \& Rubin, B.A. (2015) Influence of Communication Partner's Gender on Language. Lournal of Language and Social Psychology. Vol. 34, Issue 1, p. 46-64. doi:10.1177/0261927X14533197

Humboldt W. (1999).On Language: On the Diversity of Human Language Construction and Its Influence on the Mental Development of the Human Species. Cambridge, UK: Cambridge University press.

Jespersen, O. (1922). "The woman". Language: Its nature, development, and origin. London, GB: Allen and Unwin.

Kershen, L. (1998) American proverbs about women: $A$ reference guide. Westport, CT: Greenswood publishing group.

Koonin A. (1996). Kurs frazeologii sovremennogo anglijskogo yazyka [Course phraseology of modern English]. Moscow, Russia: Higher education.

Lakoff R. (1975). Language and Woman's Place. New York, USA: Harper.

Mauthner F (1901-1903). Beitrage zu einer Kritik der Sprache [Contributions to a Critique of Language]. Stuttgart, Germany: J.G. Cotta.

Mieder, W. (1989). American proverbs: A study of texts and contexts. Bern, Switzerland: Peter Lang.

Mieder, W, Steward, W. Kingsbery, A., \& Kelsie, B. (1992). A dictionary of American proverbs. Oxford, UK: Oxford University Press.

Mieder, W. (2002). Twisted wisdom modern antiproverbs. Hobart, Tasmania Australia: DeProverbio. com.

Mills, S. (1995). Language and gender: Interdisciplinary perspectives. London, GB: Longman.

The Oxford English Dictionary. Retrieved from http:// www.oed.com/

Perkins, G. C. (1911). The man-made world: Or, Our androcentric culture. New York, USA: Charlton.
Potapov, V. (2002). Mnogourovnevaya strategiya v lingvisticheskoj genderologii [Multilevel strategy of linguistic gender studies]. Voprosi yazikoznaniya,1, 103-130.

Preston, T. (2012). A dictionary of English proverbs and proverbial phrases. London, GB: Whittaker \& Co.

Roman C., Juhasz S., \& Miller C. (1994). The woman and language debate. A source book. New Brunswick, New Jersey: Rutgers University press.

Simpson, J., \& Speake, J. (1994). Concise Oxford Dictionary of Proverbs. Oxford, UK: Oxford University Press.

Smirnova O. (2009) Obrazy materi I otca vo frazeologii raznostrukturnyh yazykov (sopostavitelnyj analiz semanticheskih harakteristik na material anglijskogo-persidskogo russkogo i francuzskogo yazykov) [Images of the mother and father in the phraseology of the difference-structured languages (comparative analysis of semantic characteristics on the material of English, Persian, Russian and French languages] (Unpublished doctoral dissertation thesis). Pyatigorsk: Stavropol State University, Russia.

Spender, D. (1980). Man Made Language. London, GB: Routledge and Regan Paul.

Stevenson, B. (1948). The Macmillan Book of Proverbs, Maxims and Familiar Phrases. N.Y., USA: The MacMillan Company.

Tannen, D. (1990). You Just Don't Understand: Women and Men in Conversation. New York, USA: Ballantine.

The American Heritage Dictionary of the English language. Retrieved from http://ahdictionary.com/

Titelman, G. (2000). Random House of America's Popular Proverbs and Sayings. New York, USA: Random House Information Group.

Zhou, M. (2017) Motherhood, Employment, and The Dynamics of Women's gender attitudes. GENDER\&SOCIETY, Vol.31 №6 p.751-776. Doi: $10.1177 / 0891243217732320$

Walter H., \& Mokienko V. (2005). Anti-proverbs of $t$ Russian people (2nd ed.). St. Petersburg, Russia: Neva. 